\title{
Italian Director Cristina Comencini
}

\author{
By Flavia Laviosa
}

Fall 2005 Issue of KINEMA

\section{FLAVIA LAVIOSA IN CONVERSATION WITH ITALIAN DIRECTOR CRISTINA COMENCINI}

A PROLIFIC film director and screenplay writer as well as an accomplished novelist, Cristina Comencini (1956) is well known for her novels and her numerous films. Together with Francesca Archibugi (1960) and Roberta Torre (1962), she is one of the new Italian filmmakers who, in the last sixteen years, have become famous for having put forward new assertive female characters in cinema, thanks also to a good commercial distribution of her works.

Comencini's films, Zoo (1988); I divertimenti della vita privata (Amusements of the Private Life, 1990); La fine è nota (The End Is Known, 1992); Va' dove ti porta il cuore (Follow Your Heart, 1996); Matrimoni (Marriages, 1998); Liberate I pesci! (Free the Fish!, 1999); Il più bel giorno della mia vita (The Best Day of My Life, 2002); La bestia nel cuore (The Beast In the Heart, 2005); as well as her novels, Le pagine strappate (The Missing Pages, 1991); Passione di famiglia (1994); Il cappotto del turco (The Coat of the Turk, 1997); Matrioska (2000); La bestia nel cuore (2004), are deep, intense stories, both moving and hilarious, marked by unforgettable female characters.

In this interview Cristina Comencini comments on all her films illustrating how from the tale genre of Zoo she moved on to comedy with Matrimoni and Liberate I pesci. She then focuses on Il più bel giorno della mia vita where she admirably combines the themes most dear to her, producing a choral film par excellence, whose characters maintain their own space and identity though being tied to family relations. The interview also examines the kaleidoscopic nature of love, which is explored as a private affair within an intricate web of family relationships involving different generations.

Laviosa: Let's talk about your experience as a novelist. Would you say that it arises from your work as a film director or it is entirely independent?

Comencini: I have always been a writer. That is all I wanted to do. I wrote a few short stories and then a novel that was never published. As I come from a family working in cinema, later I started writing screenplays. My father was a great director and I worked with him writing screenplays for adaptations of literary texts such as La storia by Elsa Morante and Cuore by De Amicis. I studied mathematics and economics that were very far from the area of studies I chose later on. For many years I used to write in the evening and do economics research during the day. I already had two children at the time. I used to do many things when I was in my twenties. Then, I decided to devote myself entirely to writing, I left the office where I worked as a researcher of economics and began to write stories and screenplays. I sent my second book, Le pagine strappate, to Natalia Ginzburg, who had already read the first one, but had advised me not to publish it. I sent my second book without signing it because I wanted her to read it without any preconception. I did not know her, but she knew my father. Ginzburg told me she would help me to publish it. After a while we edited it together, and then it was published by Feltrinelli. In 1994, this book was published in the US, as The Missing Pages. To be precise, when I was writing screenplays, I had already written a short story, a tale set in the zoo of Rome. A producer bought it and asked me to direct the film, so I entered the world of cinema with Zoo. I did not really want to be a film director because I did not want to trace my father's footsteps. He had been so successful, I thought, that it would have been difficult for me to pursue the same career, but in the end my two identities of novelist and director came together, partly by chance, partly as a natural consequence of each other.

\section{Would you like to talk about your books?}

The dominant theme of my novels is the family. My first novel, Le pagine strappate, explores the relationship between father and daughter. It is about a father who has three daughters, he is a rather distant man, an 
economist, who at some point realizes that his younger daughter holds a secret, something she cannot tell. All of a sudden, he realizes that he does not know his daughter at all, he has spent so little time with them and now he is trying to save the relationship with his youngest child. The relationship between father and daughter is very intense, full of conflicts, but also very close. Then, I wrote Passione di famiglia, the story of a great, aristocratic Neapolitan family full of women who always play cards. It is a sort of saga, a journey through time, telling the story of this family, the whole South of Italy, and particularly of Southern Italian women. Then I wrote Il cappotto del turco, the story of two sisters, set in the Sixties and Seventies, the years of my life. During these political years the girls grow up and face these complex, adventurous years in a very different way. They are very close for a long time till one dies. The forth book, Matrioska is a novel about art where one of the two female characters is a great sculptor, an enormous matrioska who knows a lot of stories which she tells an interviewer who is going to write a book about her life. The two women get close to one another, the one who carries out the interview enters the life of the sculptor, and the sculptor's life takes her back to her own life. It is a novel about women's talent and creativity. Finally, I have just finished my last book; this one too is not about family issues (La bestia nel cuore, 2004).

\section{Are you fulfilled more as a writer or as a filmmaker?}

It depends on the different moments in my life: I could not live without writing and, if I had to choose, I would never give up writing, but I would miss cinema a lot. Cinema is something I feel deeply, it is work of great imagination; it is collective work involving human relationships too. What I love about cinema is the relationship with the actors as well as the experience of writing the screenplay. I have often thought it was not right to have two jobs, as they are both demanding, but every time I direct a film, I feel like writing a book soon afterwards, therefore, I carry on doing both cinema and literary work.

\section{What did you direct after Zoo?}

After Zoo I directed I divertimenti della vita privata, a comedy set soon after the French Revolution. It is the story of a role exchange between two women during the revolution. A prostitute takes on the role of a mother, while the mother takes part in the revolution. It is a comedy regarding misunderstandings about femininity and women's roles. Then I directed a thriller, La fine è nota, based on the beautiful novel by Geoffrey Holliday Hall that Sciascia had had translated for the Mondadori series. I think that it is one of my best films, but it was not successful at all. After this thriller I directed my first highly acclaimed film $V a$ ' dove ti porta il cuore, adapted from Susanna Tamaro's novel.

\section{One could say that you have tried different genres.}

Yes, I wrote a tale for children, an $19^{\text {th }}$ century costume comedy, a thriller, a melodrama, Va' dove ti porta il cuore, a comedy Matrimoni, and yet another comedy, Liberate $i$ pesci and a dramatic film, Il più bel giorno della mia vita. At the beginning I thought that using one genre would help me, when you start doing cinema you do not have much experience. Like conducting an orchestra, cinema is a complex work that contains many other works. I used to do auteur films within a given genre. With my last film, Il più bel giorno della mia vita, I got rid of the genre and expressed directly what I wanted to say.

\section{How do you feel about working with comedy?}

Very well. Perhaps the film that I enjoyed the most directing was Matrimoni. Part of me is extremely dramatic, but luckily I am also very ironic. Comedy belongs to the Italian tradition and it is also a family tradition, my father did many comedies. I like comedies. I love Billy Wilder, Woody Allen. You can reach lightness and depth in a comedy made up of situations rather than jokes, although you need jokes too. To me comedy seems to be very close to life, if it is well written and well performed it can breathe out a puff of life. A good comedy never ages, Billy Wilder's films, like Someone Likes it Hot, are always modern. Dramatic films instead do age. The way we conceive pain and sorrow may change from time to time, but laughter survives the test of time.

As for the films Matrimoni and Liberate i pesci, one is set in Trani, the other in Lecce. In Liberate $i$ pesci you have chosen music played by groups from Salento such as Sud Sound System, Araknè Mediterranea and Banda Ionica. Can you explain your geo-spatial and geocultural choices? 
Matrimoni is not set only in Trani. Part of the family is in Trani, the rest lives in Bologna. Matrimoni is about the escape journey of a woman on Christmas day. While the whole family was coming from the South to celebrate Christmas together, she went back to the South. Italy is a country marked by profound differences. There has always been a divide between the rich Centre-North linked to Northern Europe and the South that lags behind economically, but which is also the cradle of a rich culture. In the Campania, Sicily and Apulia regions there is a cultured elite. In Matrimoni I was interested in comparing these two worlds at both family and private life levels. It is as if through comedy and the family itself I wished to link the North and South of Italy. I liked the idea of a comedy that ran through the entire peninsula. With Matrimoni I got to know Apulia. My father was from Brescia, my mother from Naples; therefore travelling between North and South is part of my DNA. In this film I replaced Campania with Apulia because it is very difficult to deal with Campania; to me it is the most magic, extraordinary region, but also full of strong social contrasts. Apulia is the same, but the contrasts are less noticeable. When I went to Apulia to present my books, I fell in love with the region; I very much like the people and the Norman towns. Matrimoni did very well, so I thought of doing another comedy, Liberate I pesci, a grotesque genre this time, set in Apulia again.

In your films and books you look at the family through different generations, analyzing how it changes and examining its development. You narrate interpersonal relationships within and across generations. Why do you choose the family as the object of your narration?

I think that families are of great interest to literature because the novels focusing on the family are countless. Perhaps the writer feels that by observing the family microcosm and the way the family projects itself to the outside world, with its contradictions and conflicts, by analyzing the need to withdraw and open up so as not to go mad, he/she will be able to understand the way people are, what they want, how they change and stay always the same. In all the classics the family plays a central role. I come from a large family; we are four daughters and have many children of our own. I have always had the feeling I would be good at narrating the family because I know well the nuances of relationships, love and hate and how all this is intertwined. I am deeply interested in the relationship between a man and a woman because the family is built around a couple: a man and a woman, who come together, love each other and have children. The family is perhaps the thing that one wishes the most, but it is also the most difficult thing to have. For this reason I think that it is very important to tell about the evolution of the family which is always featured in my books and films.

In your films you underline the most hidden aspects of family life, bring to light, as if you were looking at them through a magnifying lens, the private secrets, lies, ambiguities, silences, misunderstandings that knit together family relationships. While you vivisect the family you highlight the fact that this institution is going through a crisis. Do you portray the family as going against new social and interpersonal relationships or do you accept it and put it forward as an irreplaceable institution with no valid alternatives?

I am working on a film in English, written by Frederic Raphael, a great screenplay writer. It is the story of the marriage between two artists, Clara Wieck and Robert Schumann in the early $19^{\text {th }}$ century. She is a great pianist, he is a great composer. It is a love marriage, but very dramatic because it is impossible to keep a family together when tow people wish to pursue their respective professional aspirations. The situation seems to me very modern. Besides, I have worked with Suso Cecchi d'Amico, a great writer in the Italian cinema, and my daughter who is a musician. Suso claims that it is impossible to keep a family together when two people try to fulfill themselves professionally. She is very pessimistic about this, she thinks that in such a relationship people start chasing each other up, the children have no space, and it is no longer possible to create a family as she knows it. I do not hold such a pessimistic view, but it is true that when both a man and a woman try to fulfill their aspirations outside the family, various contradictions ensue within the couple. This story addresses the cultural theme of the feminist movement. Only today we understand what kind of impact this change has had on people and family, what kind of suffering it has brought about, because a woman has in any case a strong desire to become a mother and the man needs to be a man. Generally speaking, those who write stories for the cinema or literature do not have recipes, what they can do is to outline some situations and lead them to their extreme consequences, delving deep into them so that each of us can understand a little bit more. Telling what happens in reality or foreseeing it in 
order to improve society is the task of historians and politicians, not mine. I have had three children and a granddaughter very early, I have always been surrounded by many children and I have always worked with children. I had the desire to hold everything together, with a gigantic effort, though. The family adapts itself to new circumstances and new realities. It is interesting to see how it is changing and tell about the earthquakes it is enduring.

In the film Il più bel giorno della mia vita, you present various kinds of love. I quote what you stated in an interview published in Repubblica on $6^{\text {th }}$ April, 2002: "[in this film] there is challenge and conflict between feelings and desire. There is this almost religious idea of unity between body and soul: I wanted to narrate this utopia, which is also the utopia of my generation." Can you please elaborate on this idea of utopia?

In the past the family was a contract, a relationship where husbands' unfaithfulness was normal. With the rare exception of love marriages, most couples used to live together in an atmosphere of indifference, or even hatred. Then in the 70s something overturned the traditional concepts of marriage and family. The youth movement was very utopian, it was made up of dreamers who wanted to link love to happiness and sex. We had to set our feelings free and make them live together with desire. Such romantic dream turned into a protest movement that led to devaluing the concept of family, regarded as an empty, false institution. The spirit of this movement expressed young people's desire to make love for love's sake, but this ideal soon had to deal with reality, thus resulting into countless separations: it is very difficult to keep a stable marriage, with children and where love and desire live for ever. I still believe in that dream, a dream whose great merit is to have revolutionized our customs and it is right to preserve it, but maybe we need to make it more realistic. The present generation, the generation of my elder children, has done so. They inherited this dream, the desire to love one another fully with body and feelings, but they also know that in order to render these marriages more stable, they need to get married later in life and think carefully about it. Nowadays there is greater awareness of the importance of these choices.

Your female characters are numerous and belong to different generations. I seem to perceive a linear portrayal of the male characters and a complex multidimensional representation of the female ones. Is your choice feminist, narrative, aesthetic or does it derive from the conviction that the female world is more complex and better suited to manage ambiguities and conflicts?

I believe that the complexity of men does not emerge in the private sphere. I think that a man is a very interesting being, but his tormented difficulty in living reveals itself only in his relationship with sex, work, career, money and knowledge. My stories talk about private worlds where the man is controlled by the woman who overtakes him thanks to her subtle ability to orchestrate the themes of love, family, tenderness, old age, beauty and ugliness. It is as if the woman spent her life thinking, imagining, dreaming about these things. This does not mean that the man is less complicated; it is only that, in order to give the best of himself, he often needs a territory outside the family. Only a few days ago I watched La dolce vita again. Fellini narrates the male complexity better than anybody else, I think together with Woody Allen. He succeeded only by portraying the man in his relationship with the woman who is waiting for him, with his flirts, his successes and failures. It is difficult to give male characters full recognition of their complexity from within the family microcosm. Bergman did so in Scenes From a Marriage, but maybe that was a special man. Men do not talk much, they therefore appear withdrawn in films about the family, just as they are in real life. In reality, all human beings, men and women, are very complicated indeed.

\section{Why have you chosen to explore the female sensitivity?}

I have just written a book inspired by a very dramatic event in real life. It features a male character I have felt deeply about for his diversity and contradictions. He is an actor and I feel I have attributed to him the same complexity and torment exhibited by my female characters. Precisely because he is fully absorbed by his work, I could follow him also in his aspirations, betrayals, thoughts and love for his partner. I think that the more you come out of the family context, the better you can describe men.

If one wanted to identify the common features of your films and define your authorial signature, what would you say are the most typical traits of your cinema?

Certainly the choice of current themes. Stylistically my films share the way of narrating the metaphysics 
of private feeling, even in the tiniest things mirroring a reality more important than us. In this sense my writing and my films express a sort of religiosity, not so much because there is God in them, but because simple facts and every day feelings become great events once they are included in the narrative. I like to move from narration to dream and realize the story-dream. This can be done especially in books, but not only there: in Il più bel giorno della mia vita for example, there is the child's dream, her fantasizing which soon leads to a real situation. It is the relationship between dream and reality that reveals aspects of what is also outside ourselves and belongs to everybody. Am I good at all this? Sometimes I am, sometimes I am not.

I would like to talk about the end of Il più bel giorno della mia vita when you give the video camera to the little girl on the day of her first communion. In an interview you say "I give the video camera to the little girl so that she can reflect on and foresee what will happen and, projected into the future, this girl knows already that she will not make the same mistakes." Which mistakes are you referring to?

Her parents' mistakes, her mother's, her father's and everything that caused her to suffer. It is irrelevant whether she too will make the same mistakes, what matters is her beautiful, terrifying feeling of having acquired an awareness which is no longer that of a child, the video camera gives her the opportunity to fix the images with adult eyes. She knows this is the last time she is seeing her parents together and registers what she is experiencing as if it were already only a memory. As a film director I liked the idea of giving the video camera to the girl who had witnessed everything in silence and letting her do her own finale. She is very different from her parents, she knows only too well their mistakes, having suffered a lot from them, and she is therefore already grown up. I think that the same thing happened to the generation next to mine, the generation of romantic dreamers in the 70 s.

All your films feature a main character that represents the new generation from which we expect something new. What do you expect from this generation?

Each generation makes one step forward. This one has a new awareness of emotional life, faithfulness, love, desire, children, although they have lost their enthusiasm somewhat. I have a daughter; she writes too and has a six-month old baby. She has reached motherhood not like me, a child who was having another child, but with great wisdom. I have the feeling that this generation will build something more stable and I wish it will succeed without losing the dream.

You have dealt a lot with women as characters portrayed in their private and social lives. I am drawing on what has been stated at the International Women Film Festival in 2003, held in Turin last March. The organizer, Clara Rivalta, declares to be promoting the diffusion of culture among women to develop and research on a new language and she talks about the specificity of female expressivity. What do you think about this? Can we talk about female aesthetics in cinema, of female themes and languages? Has a female film director a different way of making films from male directors?

It is very easy to be contradicted on this subject. It is true that some themes require sensitivity and knowledge of the female world that only a woman possesses, but it is equally true that there are great male films directors such as Bergman, Woody Allen, and my father too. I have always thought that it would be impossible to identify such a great difference and although the idea of women's groups which reflect, understand and exchange experiences is very beautiful, art is not gendered. Since ancient Greece in poetry the artist has always had the urge to abandon his or her own gender in order to portray humanity as a whole. Sometimes this is not entirely successful because not everybody is equally talented. Tolstoy is a perfect example: he created Natasha and prince Andrea, who are both at the same time a man and a woman. Tolstoy had a very old fashioned view of women, but as a writer he abandoned his gender. The artist throws over his/her back the weight of the division which we carry in our everyday lives and have been carrying through centuries, and portrays both genders. I do not like to place limits to art: art should not be limiting, but liberating.

I have here with me a list of films directed by young female directors. How is it that there are so many film directors at their first experience, whose works are followed by artistic silence? 
You could draw the same list for many men who have started their careers as directors and who then stopped or moved on to television. There has been a time when films about women became fashionable and have launched many female directors with the idea that they would produce successful films. I do not believe that women do not have the same talent as men and that there are only few female directors because they are not offered enough opportunities. I think that women are afraid, partly rightly so, to take on an authoritative role whereby they give orders to many people, this because women do not like to be authoritarian. The problem was more serious in previous decades: until fifteen years ago there was no film screenplay with prominent female roles. These days the difficulties involve the entire film production in Italy, both men and women are penalized by this.

\section{Where is the Italian cinema of the new generation going?}

We have all grown up in the shadow of magnificent cinema, my father's cinema, our parents' cinema in a wide sense, which used to tell stories of people, while narrating Italy and therefore the whole world. When we experienced ten years of strong political tension, terrorism, bomb attacks, nobody narrated anything anymore. There were only political and ideological films. Certainly there were great directors, like Bertolucci and Bellocchio who made high quality films, however the ability to tell a story had gone. Politics silenced everybody, nobody could tell non-ideological stories. It was almost a reactionary situation. In the 80s, the creative crisis of Italian cinema had to face the total anarchy established by the rapid expansion of television channels. Television used to buy films and broadcast them at every hour, day and night on seventy different channels. Already fragile, the film sector was confronted by this cultural tragedy that weakened all forms of art including sculpture, painting, theatre and music. It seemed that everything had become television. At the end of the 80s the cinema recovered and a new generation of film directors, which I belong to, began to tell very little stories in order to free themselves from political themes and to re-evaluate the human element. The smaller these stories were, the more they seemed true. It was the birth of a new series of minimalist films that at last talked about people again, rejecting social themes like the plague. Today we recognize the limits of such choices. We should narrate people's lives within a historical and geographical context as Amelio has carried on doing. We should be more ambitious: our stories and characters should talk about what is happening not only in our country but also in the whole of Europe. I wish this kind of cinema will arrive soon.

This interview took place in Rome on 11 June 2003. It was video recorded, then transcribed with the film director's permission.

\section{Author Information}

Flavia LAVIOSA is a Senior Lecturer in the Department of Italian Studies at Wellesley College. Her research focuses on Italian women directors. She has published on Francesca Archibugi and is currently working on a monograph on this director. Laviosa has also written on Cristina Comencini and the cinema produced in the Southern Italian region Apulia. 


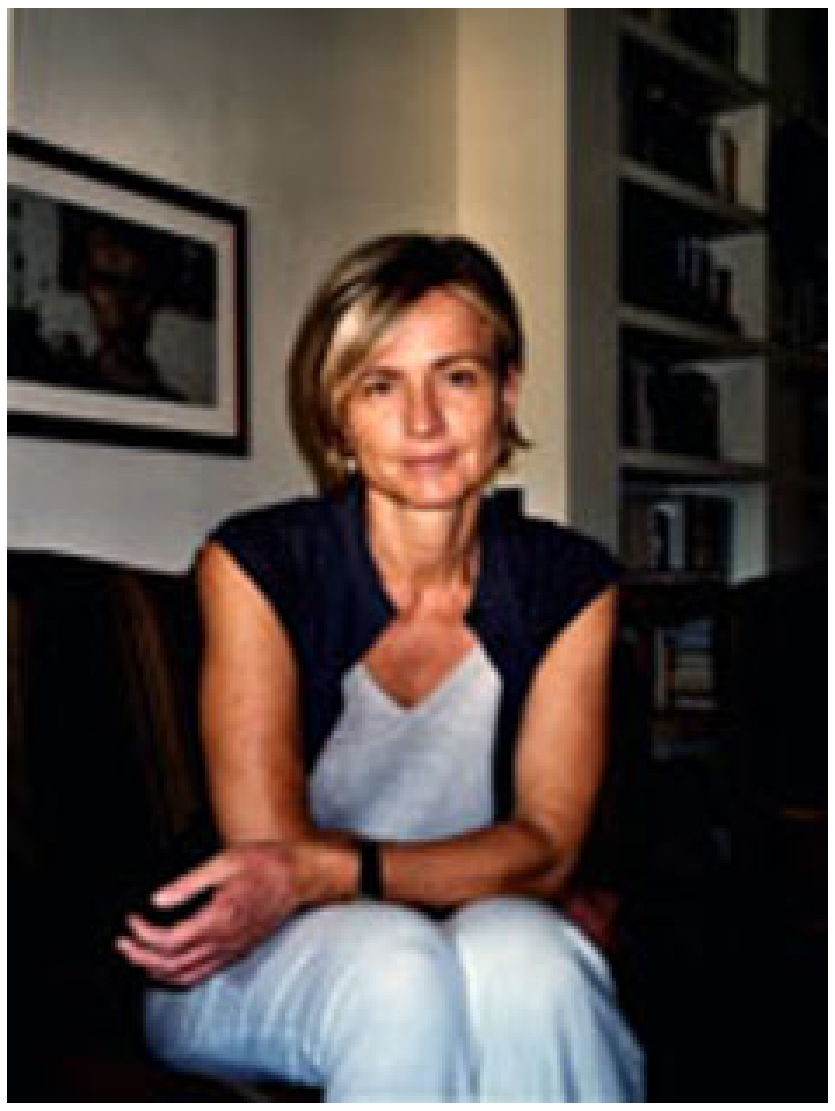

Figure 1: Director Cristina Comencini 